UNIVERSIDADE DE SÃO PAULO

INSTITUTO DE PSICOLOGIA

MAURÍCIO CERONI IVO

A IDENTIFICAÇÃO DE JOVENS COM ALTAS HABILIDADES :

UMA ABORDAGEM WINNICOTTIANA DA CRIATIVIDADE .

(2 ${ }^{\mathrm{a}}$ Versão)

SÃO PAULO

2012 
UNIVERSIDADE DE SÃO PAULO

INSTITUTO DE PSICOLOGIA

MAURÍCIO CERONI IVO

A IDENTIFICAÇÃO DE JOVENS COM ALTAS HABILIDADES :

UMA ABORDAGEM WINNICOTTIANA DA CRIATIVIDADE .

(2 $2^{\text {a }}$ ersão)

Dissertação apresentada ao Instituto de Psicologia da Universidade de São Paulo como parte dos requisitos para obtenção do grau de Mestre em Psicologia.

SÃO PAULO 
UNIVERSIDADE DE SÃO PAULO

INSTITUTO DE PSICOLOGIA

\author{
MAURÍCIO CERONI IVO
}

\title{
A IDENTIFICAÇÃO DE JOVENS COM ALTAS HABILIDADES : UMA ABORDAGEM WINNICOTTIANA DA CRIATIVIDADE .
}

\author{
(2ª Versão)
}

Dissertação apresentada ao Instituto de Psicologia da Universidade de São Paulo como parte dos requisitos para obtenção do grau de Mestre em Psicologia.

Área de Concentração: Psicologia Clínica

Orientadora: Profa. Dra.

Ivonise Fernandes da Motta

SÃO PAULO 
AUTORIZO A REPRODUÇÃO E DIVULGAÇÃO TOTAL OU PARCIAL DESTE

TRABALHO, POR QUALQUER MEIO CONVENCIONAL OU ELETRÔNICO, PARA FINS DE ESTUDO E PESQUISA, DESDE QUE CITADA A FONTE.

Catalogação na publicação

Biblioteca Dante Moreira Leite

Instituto de Psicologia da Universidade de São Paulo

Ivo, Maurício Ceroni.

A identificação de jovens com altas habilidades: uma abordagem winnicottiana da criatividade / Maurício Ceroni Ivo; orientadora Ivonise Fernandes da Motta. -- São Paulo, 2012.

$101 \mathrm{f}$.

Dissertação (Mestrado - Programa de Pós-Graduação em Psicologia. Área de Concentração: Psicologia Clinica) - Instituto de Psicologia da Universidade de São Paulo.

1. Aptidão 2. Superdotados 3. Criatividade 4. Espaço de criação (Winnicott) 5. Jovens I. Título. 
Nome: Ivo, Maurício Ceroni

Título: A identificação de jovens com altas habilidades : uma abordagem winnicottiana da criatividade .

Dissertação apresentada ao Instituto de Psicologia da Universidade de São Paulo para obtenção do título de Mestre em Psicologia.

BANCA EXAMINADORA

Presidente e Orientadora : Ivonise Fernandes da Motta

Nome e Assinatura

Nome e Assinatura

Dissertação defendida e aprovada em: 1 
À minha esposa lolanda Svetlana, pelo apoio e amor. Aos meus queridos filhos, meu orgulho e imortalidade. Aos meus familiares, amigos, presentes e ausentes. 


\section{AGRADECIMENTOS}

À Professora Doutora Ivonise Fernandes da Motta a quem devo todos os méritos desse trabalho. Seu incentivo, dedicação, generosidade, sabedoria, entusiasmo, disponibilidade e motivação foram decisivos. Obrigado por me indicar o caminho, por compartilhar momentos tão importantes para meu desenvolvimento, que transformaram minha vida.

Ao Professor Doutor José Tolentino Rosa, pelo olhar atento, apurado, instigador e sobretudo pela calma, paciência e pelas preciosas contribuições na etapa de qualificação.

Ao Professor Egberto Turato, PhD, pelas inestimáveis contribuições, sobretudo quanto às questões metodológicas.

À minha querida Dra. Iolanda Rosemary Martins - com quem tive o privilégio de dividir momentos inesquecíveis em nossas incursões winnicottianas - o meu carinho, respeito e admiração. Graças ao seu olhar e aos caminhos apontados concluo esta etapa.

A todos que colaboram no Lapecri, este laboratório que é a alma das pesquisas da Profa. Ivonise, que tanto contribui para a pesquisa e para a formação de profissionais, e em especial aos estagiários da graduação que com sua energia, disposição e formação colaboraram na parceria Ismart/Lapecri. 
À doutoranda Sandra Zanetti que é uma das profissionais mais envolvidas, competentes e dedicadas com quem tive o prazer de trabalhar.

Ao amigo Jaber Younes, que sempre incentivou e mostrou as virtudes e problemas a serem resolvidos no percurso desse trabalho.

À Prof. Dra. Sonia Parente, pelas observações precisas na qualificação.

Ao Instituto Social Maria Telles - Ismart - em especial à llona Becskeházy e Inês Boaventura França pela disponibilização dos dados que embasaram a pesquisa.

Ao CEAF - Centro de estudos e assistência à família - que realiza o trabalho em parceria com o Ismart com tanta dedicação, competência, cuidado, profissionalismo e solidariedade no trato com famílias oriundas de camadas sócio-econômicas menos favorecidas.

Ao amigo Davi Bogomoletz a quem agradeço por ter sido trazido por Deus e colocado em nosso percurso, fazendo parte de nossas vidas, de todos nós que tivemos a felicidade de desfrutar de sua companhia nas aulas de Winnicott.

À minha mãe, que sempre enalteceu os estudos, lutou e possibilitou com seu esforço, abnegação, desprendimento, abdicando de seu conforto em prol dos filhos, meu eterno e terno agradecimento.

Aos meus três filhos, Catarina, João Arthur e Luís Vitor, pelas horas cedidas de convivência para a finalização do trabalho.

E à minha querida esposa lolanda Svetlana, minha razão de viver, por ter me concedido participar de sua vida. 
Olhar para trás após uma longa caminhada pode fazer perder a noção da distância que percorremos, mas se nos detivermos em nossa imagem, quando a iniciamos e ao término, certamente nos lembraremos o quanto nos custou chegar até o ponto final, e hoje temos a impressão de que tudo começou ontem. Não somos os mesmos, mas sabemos mais uns dos outros. E é por esse motivo que dizer adeus se torna complicado! Digamos então que nada se perderá. Pelo menos dentro da gente...

João Guimarães Rosa 
SUMÁRIO

RESUMO _ _ 11

ABSTRACT 12

APRESENTAÇÃO___ 13

CAPÍTULO I - DELINEAMENTO DA PESQUISA 19

CAPÍTULO II - O LOCAL DA PESQUISA _ 21

CAPÍTULO III - O ALUNO COM ALTAS HABILIDADES EM SALA DE AULA_24

CAPÍTULO IV - DESENHO DA PESQUISA___ 30

CAPÍTULO V - WINNICOTT E A CRIATIVIDADE___ 33

CAPÍTULO VI - ANÁLISE ESTATÍSTICA _ 49

ROC CURVE

RHO DE SPEARMAN

CAPÍTULO VII - CONSIDERAÇÕES _

REFERÊNCIAS

ANEXOS 


\section{RESUMO}

Ivo, Maurício Ceroni (2012). A identificação de Jovens com Altas Habilidades : uma abordagem Winnicottiana da criatividade. Texto para Dissertação de mestrado, Instituto de Psicologia, Departamento de Psicologia Clínica, Orientadora Ivonise Fernandes da Motta, Universidade de São Paulo, São Paulo.

Este trabalho tem por finalidade pesquisar a criatividade na identificação e seleção de crianças e adolescentes portadores de altas habilidades, com carência sócioeconômica, em uma amostra de dez jovens. A superdotação ou altas habilidades tem sido objeto de estudo sobretudo quanto aos aspectos cognitivos e necessidades educacionais. Existem dois tipos de superdotação: uma acadêmica ou escolar e outra criativo-produtiva ou talentosa. A superdotação acadêmica é representada por altos níveis de desempenho escolar, boa memória, grande atividade intelectual, processamento de informações complexas, pensamento analítico, crítico e lógico. Por outro lado, a superdotação criativo-produtiva estaria mais ligada à curiosidade, resolução de problemas e características do pensamento criativo como originalidade, fluência e flexibilidade. O conceito de um indivíduo superdotado é associado a três conjuntos de traços: habilidade acima da média em alguma área do conhecimento; envolvimento com a tarefa (motivação, perseverança, concentração) e criatividade (idéias diferentes, novos significados), podendo se destacar nas seguintes áreas: acadêmica, criatividade, liderança, artística, psicomotora e motivação. O não preenchimento das vagas ofertadas para bolsistas no Projeto legitima 0 questionamento se a causa é a valorização apenas do tipo de superdotação acadêmica em detrimento da criativo-produtiva; ao pesquisar a forma como a criatividade é abordada no processo de seleção e a importância atribuída aos aspectos criativos demonstrados pelos candidatos, espera-se obter a explicação para uma oferta de vagas maior do que o número de selecionados, ainda que mil novecentos e noventa e sete candidatos tenham se candidatado ao processo. Os dados para a pesquisa são coletados por intermédio do trabalho de uma equipe de psicólogas que prestam serviços para uma Instituição sem fins lucrativos com o propósito de selecionar indivíduos com altas habilidades. Analisar-se-á de que forma a consideração do aspecto criativo desses jovens é avaliado no processo seletivo, tendo como parâmetros teóricos os conceitos para a criatividade de Winnicott, bem como autores que tratam da criatividade especificamente na superdotação, como Renzulli e Reis. A maior parte das características de indivíduos criativos, tais como autoconfiança e independência, não-conformismo, senso de humor, interesses estéticos, impulso para realização, desejo de descoberta e ordenação, estão ligadas ao conceito de self verdadeiro e do seu gesto espontâneo, bem como ao desenvolvimento da área da transicionalidade, aquela que não pertence à realidade objetiva nem à subjetiva. Apesar da criatividade ser avaliada como uma das competências que definem o desempenho do candidato e, portanto, determinam seu ingresso no projeto, não se prioriza na seleção desses jovens o aspecto criativo.

Palavras-chave: Altas Habilidades, Superdotação, Criatividade, Espaço Potencial de criatividade, Talentos. 
Ivo, Maurício Ceroni (2012). High ability identification on youngs: a winnicottian approach to creativity. Composition for Master's degree qualification exam, Institute of Psychology, Department of Clinical Psychology, Advisor Ivonise Fernandes da Motta, Universidade de São Paulo, São Paulo.

This work has the objective of researching creativity to indentify and select gifted children and teenagers with social and financial needs, within a ten individuals sample. Giftedness, or high abilities, has been object of study specially regarding the cognitive and educational needs aspects. There are two kinds of giftedness: one is academic or scholar and the other one is creative-productive or talented.The academic Giftedness is represented by the high level of school performance, good memory, great intellectual activity, processing of complex information, analytic thought, critic and logical.

On the other hand, the creative-productive giftedness would be more related to curiosity, solving problems and characteristics of creative thought such as originality, fluency and flexibility. The concept of a gifted individual is associated to three sets of traces: ability higher than the average in any field of knowledge, task involvement (motivation, perseverance, concentration) and creativity (different ideas, new meanings), standing out on the following areas: academic, creativity, leadership, artistic, psychomotor and motivation.

When scholarships are not fully distributed within the Project it legitimates questioning if the reason is the valorization of only the academic gifted individual letting aside thecreative-productive; while researching how creativity is addressed in the selection process and the importance given to the creative aspects demonstrated by the candidates, it's expected to obtain the explanation for an offer of scholarships higher than the number of selected students, even thought one thousand and ninety seven candidates have applied to the selection process.

The research data is collected by a team of psychologists through volunteer work to a Nonprofit Organization with the purpose of selecting such gifted individuals. It will be analyzed in what way the consideration of the creative aspect of these young individuals is evaluated within the selection process, having as theory parameters Winnicott's creativity concepts, as well as authors also dealing with creativity especially when the subject is giftedness, such as Renzulli and Reis.

Mostly the characteristics of creative individuals, such as self-confidence and independency, non-conformism, sense of humor, aesthetic interests, desire of discovery and to maintain order, are related to the true self concept and to its spontaneous gesture, as well as to the development in the transitional area, the area not belonging to the objective reality neither to the subjective.

Even though creativity is being evaluated as one of the subjects defining a candidates performance and, therefore, determines his or her ingress into the project, the creative aspect it's not prioritized in the selection of these young people.

Key-words: High Abilities, Giftedness, Creativity, Potential Space of Creativity, Talents. 